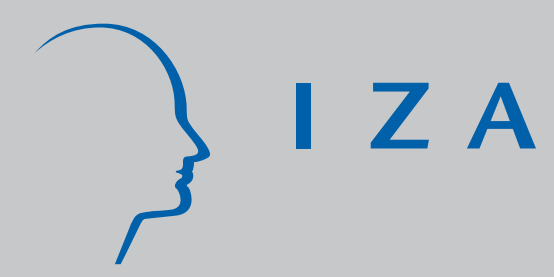

IZA DP No. 575

Human Capital and Earnings of Female Immigrants to Australia, Canada, and the United States

Heather Antecol

Deborah A. Cobb-Clark

Stephen J. Trejo

September 2002 


\title{
Human Capital and Earnings of Female Immigrants to Australia, Canada, and the United States
}

\author{
Heather Antecol \\ Claremont McKenna College \\ Deborah A. Cobb-Clark \\ SPEAR Centre, RSSS, Australian National University, and IZA Bonn \\ Stephen J. Trejo \\ University of Texas at Austin and IZA Bonn
}

Discussion Paper No. 575

September 2002

\author{
IZA \\ P.O. Box 7240 \\ D-53072 Bonn \\ Germany \\ Tel.: +49-228-3894-0 \\ Fax: +49-228-3894-210 \\ Email: iza@iza.org
}

This Discussion Paper is issued within the framework of IZA's research area The Future of Labor. Any opinions expressed here are those of the author(s) and not those of the institute. Research disseminated by IZA may include views on policy, but the institute itself takes no institutional policy positions.

The Institute for the Study of Labor (IZA) in Bonn is a local and virtual international research center and a place of communication between science, politics and business. IZA is an independent, nonprofit limited liability company (Gesellschaft mit beschränkter Haftung) supported by the Deutsche Post AG. The center is associated with the University of Bonn and offers a stimulating research environment through its research networks, research support, and visitors and doctoral programs. IZA engages in (i) original and internationally competitive research in all fields of labor economics, (ii) development of policy concepts, and (iii) dissemination of research results and concepts to the interested public. The current research program deals with (1) mobility and flexibility of labor, (2) internationalization of labor markets, (3) welfare state and labor market, (4) labor markets in transition countries, (5) the future of labor, (6) evaluation of labor market policies and projects and (7) general labor economics.

IZA Discussion Papers often represent preliminary work and are circulated to encourage discussion. Citation of such a paper should account for its provisional character. A revised version may be available on the IZA website (www.iza.org) or directly from the author. 
IZA Discussion Paper No. 575

September 2002

\section{ABSTRACT}

\section{Human Capital and Earnings of Female Immigrants to Australia, Canada, and the United States}

Census data for 1990/91 indicate that Australian and Canadian female immigrants have higher levels of English fluency, education (relative to native-born women), and income (relative to native-born women) than do U.S. female immigrants. A prominent explanation for this skill deficit of U.S. immigrant women is that the United States receives a much larger share of immigrants from Latin America than do the other two countries. Similar to previous findings for male immigrants, the apparent skill disadvantage of foreign-born women in the United States (relative to foreign-born women in Australia and Canada) shrinks dramatically once we exclude immigrants originating in Latin America. In all three countries, men are much more likely than women to gain admission on the basis of immigration criteria related to labor market considerations rather than family relationships. For this reason, we might expect that the stronger emphasis on skill-based admissions in Australia and Canada compared to the United States would have a larger impact on cross-country differences in the skill content of male rather than female immigration flows. Therefore, our findings of similar patterns for men and women and of the key role played by national origin both suggest that factors other than immigration policy per se are important contributors to the observed skill differences between immigrants to these three destination countries.

JEL Classification: J61, J68, J31

Keywords: immigration, female immigrants, human capital

Corresponding author:

Steve Trejo

Department of Economics

University of Texas

Austin, TX 78712-1173

USA

Tel.: +1 (512) 475-8512

Fax: +1 (512) 471-3510

Email: trejo@eco.utexas.edu 


\section{Introduction}

The international migration of women is an important demographic phenomenon worldwide. For example, the United Nations reports that of the 77 million people who were enumerated in various national censuses between 1970-1986 as living outside their country of birth, 48 percent were women (UN, 1995). While immigration streams in many corners of the world (most notably Africa and parts of Asia) are male-dominated, in the major immigrant receiving nations such as Australia, Canada, and the United States, women have figured prominently in the immigration flow for many decades. Female immigrants to the United States have actually outnumbered their male counterparts in every period since 1930 (Houstoun, Kramer, and Barrett, 1984; UN, 1995, Table 2), ${ }^{1}$ and since 1960 in Australia and Canada the proportion of all immigrants who are women has exceeded 45 percent (Madden and Young, 1993; UN, 1995, Table 2). Despite the fact that, worldwide, immigrants are as likely to be women as men, much of the immigration literature has tended to focus exclusively on men. ${ }^{2}$

Our objective is to contribute to an emerging literature on the experiences of female immigrants by comparing the observable skills—-language fluency, education, and income —of female immigrants to Australia, Canada, and the United States. While we (Antecol, Cobb-Clark, and Trejo, 2002) and others (Duleep and Regets, 1992; Borjas, 1993) have examined these issues for men, little is known about how the skills of female immigrants vary across destination countries. ${ }^{3}$

\footnotetext{
${ }^{1}$ The single exception appears to be 1980-1984, although the sex composition of immigrants for fiscal year 1980-1981 cannot be determined (UN, 1995).

${ }^{2}$ There are exceptions. For example, Reitz (1998) uses 1980 Census data for the United States and 1981 Census data for Australia and Canada to examine the role that human capital factors (e.g., education) and labor market institutions (e.g., unionization) play in generating cross-national differences in entry-level earnings of both male and female immigrants in the urban labor force. Further, Reitz et. al. (1999) conduct a similar analysis for Canada and Germany using the first wave of the 1984 German SocioEconomic Panel and the 1986 Canadian Census.

${ }^{3}$ There is a growing literature that examines the labor market assimilation of female immigrants; see for example, Funkhouser and Trejo (1998) and Schoeni (1998).
} 
This exercise is important for a number of reasons. First, much of the current debate about legal immigration centers on how best to craft the policies used to select immigrants. In general, there has been a movement towards more skill-based selection criteria. In the United States, for example, concerns about declining skill level among the immigrant population (Borjas 1995) have prompted calls for an increased emphasis on skills in the immigrant selection process. In light of this debate, it is important to understand how immigration policy influences immigrant skill levels. Second, there appear to be substantial differences in the extent to which policy is used to select immigrant men and women for their labor market skills. There are important gender differences in the distribution of immigrants across visa categories. In addition, women disproportionately migrate as dependents of principal applicants and as such are not subject to any specific selection criteria. Thus, it is important to consider women explicitly.

A comparative analysis of Australia, Canada, and the United States provides a productive way of addressing these issues. While their economies are similar in many fundamental respects and they share a common history as major immigrant receiving countries, ${ }^{4}$ labor market policies and institutions differ markedly across these countries. Most importantly, while U.S. immigration policy is primarily one of family reunification, Australia and Canada have made a number of attempts to screen workers on the basis of special skills or high education levels (Boyd, 1976; Price, 1979; Green and Green, 1995). This institutional variation provides a means of assessing the effects of policy on the skills of immigrants.

Our results indicate that, overall, women immigrating to Australia and Canada are more skilled than women immigrating to the United States. They are more likely to be fluent in the

\footnotetext{
${ }^{4}$ During the period 1975-80, for example, nearly two-thirds of all immigrants chose one of these three countries as their destination (Borjas 1991). More recently, other countries have emerged as important immigrant destinations, but Australia, Canada, and the United States remain dominant receiving countries.
} 
destination country language, have higher levels of education (relative to native-born women), and have higher incomes (relative to native-born women) than their U.S. counterparts. To a large degree, however, the skill deficit of U.S. female immigrants is driven by the relatively high proportion of them who hail from Central and South America. Consistent with previous findings for men (Duleep and Regets, 1992; Borjas, 1993; Antecol, Cobb-Clark, and Trejo, 2002), the observable skills of foreign-born women in Australia, Canada, and the United States look quite similar once we consider only those immigrants originating outside of Latin America.

In the following section of the paper we provide institutional detail about the immigration programs of Australia, Canada, and the United States and consider how these programs are expected to influence the skills of female immigrants. An overview of each or our data sources and estimation samples is provided in Section III. In Sections IV, V, and VI we assess how the language fluency, educational attainment, and income of female immigrants varies across destination countries. Finally, our conclusions are presented in Section VII.

\section{Immigration Policy and the Skills of Female Immigrants}

In Australia and Canada, "independent" migrants without immediate relatives are selected on the basis of a "points test" that takes into account factors such as the applicant's age, education, language ability, and occupation. ${ }^{5}$ Immigrants are also selected because they have special talents or because they meet certain investment requirements and intend to establish a business in Australia or Canada. Immigrants entering Australia or Canada through any of these avenues are typically categorized as "skilled" immigrants because the human capital and potential labor market success of

\footnotetext{
${ }^{5}$ Some applicants with relatives in the destination country are also evaluated by a points test, with the number of points required for admission lowered when the family relationship is sufficiently close.
} 
the applicants play a key role in their admission. In contrast, "family" immigrants consist of those applicants admitted solely on the basis of having an immediate relative in the destination country, and "refugees" are admitted on humanitarian grounds.

In the United States, immediate family members of U.S. citizens are "numerically unlimited" and can enter without counting against the overall cap set for annual immigrant admissions. "Numerically limited" family immigrants include more distant relatives of U.S. citizens and the immediate relatives of U.S. permanent residents. In 1990, these individuals entered the United States under one of four family-related preference categories (first, second, fourth, or fifth). U.S. immigrants entering under the third or sixth preference categories are considered to be "skilled" because their occupation or labor market skills played a role in their admission. ${ }^{6,7}$

Skills play a much larger role in immigrant selection in Australia and Canada than in the United States (Boyd 1976; Price 1979; Green and Green 1995). Around 1990, half of Australian immigrants and almost 40 percent of Canadian immigrants were admitted because of their labor market skills, whereas less than 10 percent of U.S. immigrants gained entry in this way. ${ }^{8}$ Conversely, two-thirds of U.S. immigrants were admitted on the basis of their family relationships, as compared with only a quarter of Australian immigrants and 37 percent of Canadian immigrants. ${ }^{9}$ The relative importance of skilled versus family migration varies somewhat across regions of origin,

\footnotetext{
${ }^{6}$ Rather than ranking family- and skill-based immigrants under a single preference system, the 1990 Immigration Act established a three-track preference system for family-sponsored, employment-based, and diversity immigrants (Vialet and Eig, 1990). Our data pre-date this change in policy, however.

${ }^{7}$ For detailed discussions of immigration policy in these three countries, see Boyd (1976), Briggs (1984), Chiswick (1987), Borjas (1988), Vialet (1989), Cobb-Clark (1990), Reimers and Troper (1992), Green (1995), Green and Green (1995), Lack and Templeton (1995), and Reitz (1998).

${ }^{8}$ The "skilled" category includes the immediate family members who accompany those admitted on the basis of their labor market skills. Therefore, these figures overstate the number of immigrants granted entry because of their own skills rather than family relationships, but adjusting for this feature of the reported data would not alter the conclusion that the skilled category constitutes a much larger share of immigrant admissions in Australia and Canada than in the United States. In addition, these figures pertain only to legal admissions. The sizeable flow of undocumented migrants entering the United States outside formal channels implies that the share of all U.S. migrants admitted because of their skills is even lower than the reported figures suggest.
} 
but for all source regions the share of skilled immigrants is much higher and the share of family immigrants is much lower in Australia and Canada than in the United States. Furthermore, although the share of immigrants admitted under a point system has varied over time, particularly for Canada, since at least the early 1970 s the percentage of immigrants admitted on the basis of labor market criteria has been much higher in Australia and Canada than in the United States (Wright and Maxim, 1993; Reitz, 1998).

There are, however, important gender differences in the visa categories through which immigrants gain admission. In fiscal year 1990-91, for example, men immigrating to Australia were about equally likely to have entered in a skilled migration category as in a family migration category, whereas female immigrants were much more likely to have entered in a family category (Madden and Young, 1993; UN, 1995). A similar pattern holds in Canada and the United States: compared to male immigrants, women are under-represented in skilled migration categories and over-represented in family migration categories (Houstoun, Kramer, and Barrett, 1984; UN, 1995). In general, women are much more likely than men to gain immigrant status though their family ties to other immigrants or to receiving-country citizens and residents. ${ }^{10}$

How might these differences in immigration policy influence the skill content of immigrant flows to the three destination countries? On the one hand, the Australian and Canadian practice of admitting a large fraction of immigrants through a point system that screens for labor market skills suggests that these countries should receive a more skilled immigrant flow than the United States. On the other hand, the theory of selective migration (Borjas 1991) predicts that the generous redistribution systems and relatively egalitarian wage structures in Australia and Canada work in the

\footnotetext{
${ }^{9}$ The cited figures are from Antecol, Cobb-Clark, and Trejo (2002). See that paper for details and further discussion.

${ }^{10}$ Houstoun, Kramer, and Barrett (1984) conclude that more than 90 percent of the overall sex differential in immigrant admissions to the United States can be accounted for by the preponderance of women among immediate family members.
} 
opposite direction by attracting less skilled immigrants residing in the bottom half of the income distribution. ${ }^{11}$ Because of these conflicting forces, it is not immediately obvious how differences in immigration policies and institutional frameworks across these countries will affect the skill selectivity of immigrant flows.

To a large extent, however, the immigration point systems employed in Australia and Canada select immigrants based on easily observed characteristics such as age, education, language, and occupation. In terms of these characteristics, immigrants to Australia and Canada should be more productive than those migrating to the United States. Our tests of this hypothesis will reveal how successful immigration point systems are, in practice, at selecting immigrants with favorable skill measures, and how much this screening process raises the labor market productivity of immigrant workers. $^{12}$

Interestingly, the opposite pattern should emerge if we first control for the characteristics that immigrant point systems screen on. In particular, among immigrants with similar observable skill measures, the most productive should locate in the United States where there is less social insurance against poor labor market outcomes but a greater individual return to favorable outcomes. Our tests of this hypothesis will indicate to what extent immigrant location choices based on difficult-toobserve attributes, such as ability and ambition, are able to undo the selectivity intended by point systems. Alternatively, a finding that Australian and Canadian immigrants are superior to U.S.

\footnotetext{
${ }^{11}$ For many reasons (stronger labor unions, higher minimum wages, national health insurance, more generous unemployment insurance and welfare systems), workers in the lower end of the income distribution are generally better off in Australia and Canada than in the United States, especially relative to the average worker in each country (Card and Freeman 1993; Gregory and Daly 1994).

${ }^{12}$ For several reasons, it is not a foregone conclusion that the Australian and Canadian systems lead to an immigrant flow that is highly selective in terms of characteristics associated with labor market success. First, both systems admit many immigrants who are not screened by a points test, including applicants with immediate family who are citizens of the destination country, refugees, and the family members who accompany those admitted by a points test. Second, both systems award a significant number of points based on a "personal assessment" of the applicant by the immigration official conducting the face-toface interview. Finally, Reitz (1998) argues that the Australian and Canadian points tests can be passed by applicants with quite modest skill levels, and therefore these tests may provide only very weak filters for immigrant labor market skills.
} 
immigrants in terms of unobservable as well as observable determinants of earnings would suggest that the "personal assessment" portion of a point system successfully screens for some of the difficult-to-observe attributes related to labor market productivity.

Finally, recall that, in all three countries, men are much more likely than women to gain admission on the basis of immigration criteria related to labor market considerations rather than family relationships. For this reason, we might expect that the stronger emphasis on skill-based admissions in Australia and Canada compared to the United States would have a larger impact on cross-country differences in the skill content of male rather than female immigration flows.

\section{Data}

Individual-level data from the 1991 Australian and Canadian censuses and the 1990 U.S. census are used throughout the analysis. These censuses provide comparable data on demographic characteristics, labor force behavior, country of birth, and year of arrival for immigrants in each of the three countries. ${ }^{13,14}$ The large samples available in census data are ideal for our purposes, because immigrants constitute a small fraction of the total population, and it will be important to disaggregate the immigrant population according to variables such as year of arrival and country of origin.

Our analysis is restricted to women between the ages of 25 and 59 who are not institutional

${ }^{13}$ In this paper, we use the term "immigrant" as synonymous with foreign-born individuals, in contrast to the official terminology used by the U.S. Immigration and Naturalization Service in which immigrants are legal permanent residents, and other foreigners such as tourists, business travelers, and recent refugee arrivals are "nonimmigrant aliens." The census data analyzed here cannot make such distinctions among foreign-born individuals.

${ }^{14}$ The Australian data constitute a one-percent sample of the population, while the Canadian data form a three-percent sample and the U.S. data represent a five-percent sample. Thus, the U.S. sample is much larger than the other two samples. To lighten the computational burden, we employ a .1 percent (or 1 in a 1000) sample of U.S. natives, but we use the full 5 percent sample of U.S. immigrants, and we use the full samples of natives and immigrants available in the Australian and Canadian data. The Australian and Canadian census data are self-weighting, whereas the 1990 U.S. census provides sampling weights that we use in all of the calculations reported in the paper. 
residents. This allows us to concentrate on women who have completed their formal schooling and who are in prime working ages. To control for cross-country differences in social or economic conditions or in how the census data were collected, outcomes for immigrants will be compared to outcomes for otherwise similar native-born women. To increase comparability of the native samples and improve their usefulness as a comparison group, non-whites are excluded from the native (but not the immigrant) samples. ${ }^{15}$ Finally, residents of the Atlantic Provinces and the Territories are excluded from the Canadian samples, because for these individuals the information about country of birth and year of immigration is not reported in sufficient detail.

These restrictions produce final samples of immigrant women totaling 10,948 for Australia, 39,016 for Canada, and 309,903 for the United States. Table 1 displays the region of birth distribution of those female immigrants arriving in the ten years prior to the census. In some cases, the proportion of the total immigrant flow arriving from a particular region of birth is similar across destination countries. For example, despite considerable variation in the geographic distance between source and destination countries, women from the Philippines make up about 7 percent of the female immigrant flow into all three countries. In other cases, however, destination countries receive dramatically different shares of female immigrants from particular source regions. Most importantly, close to half of women immigrating to the United States after 1980 hail from Central or South America (including Mexico and the Caribbean), whereas the same is true of only 16 percent of Canadian immigrants and less than 3 percent of Australian immigrants. In Australia and Canada, a quarter or more of recent female immigrants originated in either the United Kingdom or Europe, compared to the corresponding figure of only 11 percent in the United States. ${ }^{16}$ Another difference is

\footnotetext{
${ }^{15}$ In particular, we exclude blacks, Asians, Hispanics, and aboriginals from the native sample for each destination country.

${ }^{16}$ In Table 1, Europe is defined to include the former USSR.
} 
that Asians make up a somewhat larger share of the immigrant flow to Australia (40 percent) and Canada (42 percent) than to the United States (32 percent). Lastly, note that Australia receives a sizeable number of immigrants from New Zealand.

Although in general these patterns for female immigrants closely resemble those observed for men, the Philippines is an important exception (Antecol, Cobb-Clark, and Trejo, 2002). While only 2.4 percent of recent male immigrants enumerated in the Australian census were born in the Philippines, this was true of 7.6 percent of female immigrants. Similar disparities show up in the Filipino shares of male (4.0 and 4.1 percent) and female ( 7.1 and 6.9 percent) immigrants in Canada and the United States, respectively. These differences imply that Filipino migration to the three destination countries is heavily female. In Australia, fully 76 percent of Filipino immigrants arriving after 1980 are women, and the analogous figures are 65 percent for Canada and 61 for the United States. $^{17}$

\section{Fluency in the Destination Country Language}

Measures of English language ability are very similar in the Australian and U.S. censuses. In each case, respondents were first asked whether they speak a language other than English at home. Individuals responding affirmatively were then asked whether they spoke English "very well," "well," "not well," or "not at all." In the Australian and U.S. data, individuals are defined as "fluent in the destination country language" if they speak English at home or if they report speaking English "very well" or "well." Unfortunately, the language questions in the Canadian census are not directly comparable with the Australian and U.S. questions. When using the Canadian data, individuals are

${ }^{17}$ Overall, among post-1980 arrivals, women constituted 50 percent of the immigrant population in Australia, 51 percent in Canada, and 48 percent in the United States. 
defined as fluent in the destination country language if they report being able to conduct a conversation in either English or French. ${ }^{18}$

Given these definitions, Table 2 reports for each destination country the percent of immigrant women who are fluent in the native language, by five-year arrival cohorts. ${ }^{19}$ In all three destination countries, immigrant fluency rates rise monotonically with the length of time since arrival. This pattern is largely due to the fact that immigrants who do not speak the destination country language when they arrive tend to acquire fluency over time as they adapt to their new home. We must caution, however, that differences between immigrant arrival cohorts observed at a single point in time may reflect permanent differences between these cohorts as well as the changes that occur for a given cohort as it spends more time in the destination country. ${ }^{20}$

For every arrival cohort, fluency rates are lower for U.S. immigrants than for Australian and Canadian immigrants, and the gap is particularly large for cohorts arriving after 1970. For example, among the most recent immigrants (those arriving within five years of the census), only 56 percent of U.S. immigrants are fluent, as compared to 79 percent of Australian immigrants and 86 percent of Canadian immigrants. This gap does not disappear with time. Even among immigrants who have spent 15-20 years in the destination country (1971-75 arrivals), the fluency rate of U.S. immigrants (77 percent) is well below that of Australian immigrants (91 percent) and Canadian immigrants (96

\footnotetext{
${ }^{18}$ In their study of immigrants to Canada and the United States, Duleep and Regets (1992) use these same definitions in an attempt to create roughly comparable measures of language fluency from the 1981 Canadian census and the 1980 U.S. census.

${ }^{19}$ The intervals listed in Table 2 (and in subsequent tables) for the immigrant arrival cohorts are those that pertain to the Australian and Canadian data; the slightly different immigrant cohorts that pertain to the U.S. data are as follows: pre-1970, 1970-74, 1975-79, 1980-84, and 1985-90. For ease of exposition, henceforth we will refer to particular immigrant cohorts using the year intervals that pertain to the Australian and Canadian data, with the implied understanding that in the U.S. data the actual cohort intervals begin and end one year earlier.

${ }^{20}$ By tracking cohorts of U.S. immigrants between the 1980 and 1990 censuses, Carliner $(1995,1996)$ and Funkhouser (1996) show that English proficiency does indeed improve markedly with duration of U.S. residence and that this improvement plays an important role in immigrant wage growth.
} 
percent). ${ }^{21}$

Does the fluency deficit of U.S. immigrants arise because the Australian and Canadian point systems are successful at screening the language ability of applicants? Previous results for men (Duleep and Regets, 1992; Borjas, 1993; Antecol, Cobb-Clark, and Trejo, 2002) suggest that, to a large extent, differences in immigrant skills across destination countries are driven by the national origin mix of the immigrant flow. To explore whether a similar pattern holds for women, Table 3 reports fluency rates separately by immigrant region of birth. In this table, we limit the sample to female immigrants who have been in the destination country for ten years or less. ${ }^{22}$ The comparison between Australia and the United States is particularly informative given the similarities in how fluency is measured in these censuses. Immigrant women from a given source country generally report similar levels of English language ability in Australia and the United States. Even so, the overall fluency rate for U.S. immigrants (59 percent) falls well short of the Australian rate (77 percent). This fluency deficit of female immigrants in the United States is due in large part to the sizeable share of Latin Americans in the U.S. immigration flow. Once Latin American immigrants are excluded, 71 percent of female immigrants in the United States report being fluent in English, as compared to 78 percent of immigrant women in Australia.

Even among women originating outside of Latin America, however, English fluency is lower for U.S. immigrants than for Australian immigrants. In particular, immigrants from Asian countries tend to speak English at higher rates in Australia than in the United States. After excluding Latin American immigrants, the remaining fluency gap of 7 percentage points for foreign-born women in

\footnotetext{
${ }^{21}$ Note that the relative fluency of Canadian immigrants is probably overstated because of the particular wording of the language questions asked in the Canadian census. The U.S. and Australian language measures are much more comparable.

${ }^{22}$ In Table 3, we also exclude immigrants from the four source regions listed in Table 1 that cannot be defined for all three destination countries. The excluded regions are the following: United States, Other North America, Oceania/Antarctica, and Other.
} 
the United Sates relative to their Australian counterparts is larger than the corresponding gap of less than 3 percentage points observed for men (Antecol, Cobb-Clark, and Trejo, 2002). Therefore, although a large portion of the overall fluency gap of U.S. immigrants is attributable to national origin, this factor is somewhat less important for women than for men.

\section{Education}

We turn now to education. Table 4 reports the results of least squares regressions in which the dependent variable is years of schooling and the independent variables include dummies identifying arrival cohorts. ${ }^{23}$ Natives as well as immigrants are included in the analysis. Model 1 (see column 1) includes only the arrival cohort dummies and as a result the intercepts represent the average education level of natives in each destination country, while the coefficients on the arrival cohort dummies reflect the education differentials between immigrants in each arrival cohort and natives. U.S. native-born women have the highest mean education level, (13.2 years), followed by Canadian-born women (12.6), and Australian-born women (11.3). ${ }^{24}$ Female immigrants in the United States have between one and two fewer years of education than do native-born U.S. women. Female immigrants in Canada also have less education than their native-born counterparts although the gap is much smaller in magnitude and the difference is not always statistically significant. Women migrating to Australia, however, are relatively more educated than Australian-born women.

Model 2 (see column 2) includes dummy variables identifying five-year age groups. In these regressions, the intercepts now represent the average education level of 25-29 year-old natives (the omitted age group), the arrival cohort coefficients measure immigrant-native differentials after

\footnotetext{
${ }^{23}$ Robust standard errors are reported throughout the paper.

${ }^{24}$ This pattern of education differences for the native born in each of the three countries is similar to what Evans, Kelley, and Wanner (1998) and Reitz (1998) report.
} 
conditioning on age, and the coefficients on the age dummies reflect education differentials between each age group and 25-29 year-olds. Controlling for age, which captures the secular rise in schooling levels that took place over this period, has little effect on the estimated immigrant-native schooling differentials or on the conclusion that the United States and Canada have been less successful than Australia in attracting female immigrants with more education than native-born women.

Interestingly, the relative education disadvantage of immigrant women in the United States and the relative education advantage of immigrant women in Australia are similar to what we found previously for men (Antecol, Cobb-Clark, and Trejo, 2002). Among U.S. men, immigrants average one to two fewer years of schooling than natives, just as reported here for women. Among Australian men, immigrants possess more schooling than natives, which is what we find for women. In Canada, however, immigrant-native comparisons differ by gender. Compared to their native-born counterparts, foreign-born Canadian men have more education, whereas foreign-born Canadian women tend to have less. Given the similarities in the schooling levels of native-born men and women in Canada, these patterns suggest that Canada's attempts to encourage the immigration of highly-educated individuals have been more successful among men then women. This result is not surprising because women often immigrate to Canada as dependent family members for whom no selection criteria apply.

The educational attainment of women arriving after 1980/81 is presented in Table 5 by region of birth. Average years of schooling for women in each destination country are reported in the first three columns. Within most regions of origin, the average education of female immigrants to the United States is generally as high or higher than that of female immigrants to Australia and Canada. Overall, however, foreign-born women in the United States have substantially less schooling (gaps of 1.2-1.4 years) than foreign-born women in the other two destination countries. As was the case with 
language fluency, the explanation for this pattern is the large share of female immigrants from Latin America in the U.S. immigration flow. Women migrating to the United States from Central and South America average less than 10 years of schooling, which is very low when compared to the corresponding average for either U.S. native-born women or for Central and South American women who immigrate to Australia or Canada. Excluding Latin American immigrants from the calculations causes the mean education level of U.S. immigrants to jump from 11.3 years to 12.8 years. After making this exclusion, female immigrants to the United States have slightly more education than women migrating to Australia and Canada.

These kinds of international comparisons of educational levels might be distorted by differences across countries in educational practices and in the census questions used to elicit information about educational attainment. Within destination country, however, we would expect such factors to affect the measured education level of immigrants and natives in the same way. Therefore, we also examine a relative education measure (see the last three columns of Table 5), which is defined as the difference in average years of schooling between a particular immigrant group and natives in the same destination country. When we consider only recent female immigrants who are not from Latin America (the bottom row of Table 5), we find that Australian immigrants average 1.3 years more schooling than do native-born Australian women, Canadian immigrants have essentially the same education level as native-born Canadian women, and American immigrants have about a third of a year less schooling than native-born women in the United States. By this relative education measure, then, excluding immigrants from Central and South America dramatically shrinks - but does not completely eliminate - the educational disadvantage of foreign-born U.S. women compared to their counterparts in Australia and Canada. Regardless of whether immigrant education is measured in absolute terms or relative to natives, however, the overall educational gap 
between U.S. female immigrants and immigrant women in the other two destination countries arises in large part because the United States receives a sizeable flow of comparatively uneducated immigrants from Latin America.

\section{Income}

We turn now to a consideration of personal income. An analysis of personal incomeholding constant observable productivity-related characteristics — sheds light on how country-specific immigration policies influence the unobserved skills of immigrants. Ideally, we would prefer to analyze earnings rather than income, but unfortunately the Australian data do not distinguish earnings from other income sources. ${ }^{25}$ To increase the correspondence between income and earnings, in this section we will restrict our estimation samples to employed women. ${ }^{26,27}$ The income and employment measures in the Australian data refer to the usual week and the census survey week, respectively, whereas in the Canadian and U.S. data these measures refer to the calendar year preceding the census. We have converted the Canadian and U.S. income measures to a weekly basis so as to match the Australian data. ${ }^{28}$

For these samples of employed immigrant and native-born women, Tables 6 and 7 present

${ }^{25}$ Earnings information is available in the Canadian and U.S. censuses, however, and for these two countries we have replicated the analyses reported below using earnings rather than income as the dependent variable. The income and earnings regressions produce similar results.

${ }^{26}$ In the Canadian sample, we also exclude immigrants who arrived during the census year (1991), because income data are not available for these recent arrivals.

${ }^{27}$ Restricting the sample to employed women raises the potential for selection bias, as employment rates are likely to be correlated with labor market opportunities. Under certain circumstances, statistical techniques can be used to adjust for this bias (Heckman, 1980), but the data that we analyze here do not provide the information necessary to make credible adjustments of this type.

${ }^{28}$ Another difference between the income measures available for each country is that the Australian census reports income in fourteen intervals, whereas the Canadian and U.S. censuses provide continuous measures of income. For Australia, we use the midpoints of the reported income intervals to construct the income variable employed in our regressions. For Canada and the United States, the results reported here employ a continuous income variable, but we obtain similar results when we instead group these data into intervals and assign midpoints so as to mimic the Australian data. 
OLS estimates of the determinants of weekly income. ${ }^{29}$ Two specifications are reported for each destination country. In model 1 , the independent variables include immigrant arrival cohort dummies, age dummies, controls for geographic location, and indicators for hours worked during the census survey week. The coefficients of the geographic location and weekly hours of work variables are restricted to be the same for immigrants and natives, whereas the coefficients of the age dummies are allowed to vary by nativity. Model 2 also includes a measure of years of schooling-which is allowed to vary by nativity — and indicators for fluency in the language of the destination country.

The estimated cohort effects from these regressions are presented in Table 6, and Table 7 reports the coefficients of the age, education, and language fluency variables. In model 1, the cohort coefficients have been normalized to represent immigrant-native income differentials for women who are aged 25-29, whereas in model 2 the cohort coefficients represent the same differentials for women aged 25-29 with 12 years of education. ${ }^{30}$ To facilitate interpretation, the immigrant-native income differentials implied by these regressions are also depicted in Figure 1. Model 1 is shown in the top panel, and model 2 is shown in the bottom panel of Figure $1 .^{31}$ Each line in the figure corresponds to a different destination country, and immigrant arrival cohorts are distinguished by years since arrival, which is measured along the horizontal axis.

These graphs are only intended to illustrate the income differences between immigrants of various arrival cohorts and natives at a given point in time. The plots are not meant to portray the

\footnotetext{
${ }^{29}$ The dependent variable in these regressions is the natural logarithm of weekly personal income.

${ }^{30}$ Note that the interactions between nativity and age in these regressions imply that the immigrant-native income gaps presented in Table 7 for ages 25-29 will differ at older ages.

${ }^{31}$ To control for age differences, both across countries and between immigrants and natives within a country, these calculations assign the same age distribution to all groups. In particular, we use the age distribution observed for our sample of U.S. immigrants: 18.0 percent are in the 25-29 age range, 18.9 percent are 30-34, 17.4 percent are 35-39, 16.1 percent are 40-44, 12.5 percent are 45-49, 10.0 percent are 50-54, and 7.1 percent are 55-59. Because the immigrant-native income differentials estimated for each country are allowed to vary by age group, the overall differentials shown in Figure 1 depend on the particular age distribution used. However, similar patterns emerge from using the age distributions observed for any of the immigrant or native samples in our three destination countries. Note that the calculations displayed in the bottom panel of Figure 1 pertain to individuals with 12 years of
} 
life-cycle trajectories of immigrants as they gain experience in the destination country labor market, because analyses of immigrant outcomes using a single cross section of data cannot distinguish assimilation and cohort effects.

When we do not control for education and language ability (the top panel of Figure 1), the income gap between female immigrants and their native-born counterparts is largest in the United States and smallest in Australia, with Canada falling in between but not too different from the United States. Once we condition on education and language fluency (the bottom panel of Figure 1), however, this gap shrinks dramatically in the United States. Now, the relative income disadvantage of female immigrants to the United States is smaller than that of women migrating to Australia or Canada, except for the most recent arrival cohort of Australian immigrants. These comparisons suggest that the smaller income deficits (relative to natives) initially observed for immigrant women in Australia and Canada are largely explained by their higher levels of education and language ability. Once we control for these observable skill measures, the relative incomes of female immigrants in the United States are higher than those of Canadian immigrants from all arrival cohorts and are higher than those of Australian immigrants from all cohorts but the most recent.

In Australia, immigrant-native income differences are relatively small to begin with, do not change much after controlling for education and fluency, and vary little by immigrant year of arrival. In addition, Table 7 indicates that although the economic return to a year of schooling for nativeborn women is much higher in the United States (10.4 percent) and Canada (9.3 percent) than in Australia (6.6 percent), the return to education for immigrant women is similar in all three countries (ranging from 5.4 percent in Australia to 5.7 percent in the United States). Therefore, both in terms of the intercept and the return to education, the wage structure is much more similar for immigrant 
and native-born women in Australia than in Canada or the United States. Previously, we found this same pattern for men (Antecol, Cobb-Clark, and Trejo, 2002).

Tables 8 and 9 along with Figure 2 replicate the preceding analysis of immigrant-native income differentials, but now excluding women born in Central and South America. This exclusion has little effect on the immigrant income gaps estimated for Australia or Canada, which is not surprising because Latin American immigrants constitute a small share of the overall immigration flow into these countries. In the United States, however, excluding women born in Central and South America serves to substantially reduce the immigrant income disadvantage (compare the top panels of Figures 1 and 2). In fact, the impact of excluding Latin American immigrants on immigrant-native income differentials in the United States is similar to the impact of controlling for English fluency and education (compare the bottom panel of Figure 1 with the top panel of Figure 2), a finding that reflects the very low levels of fluency and schooling possessed by U.S. immigrants from Latin America (as we documented earlier in Tables 3 and 5). The income analyses display the same general pattern that we have already seen for language fluency and education: unskilled immigration from Latin America accounts for a large portion of the overall gap in human capital between U.S. female immigrants and women migrating to Australia and Canada. Once again, these results for women mirror our previous findings for men (Antecol, Cobb-Clark, and Trejo, 2002).

Even after excluding women from Latin American, however, the incomes of U.S. immigrants improve relative to Australian and Canadian immigrants once controls are added for fluency and schooling (compare the top and bottom panels of Figure 2). Because the immigration point systems in Australia and Canada explicitly screen for language ability and education, this finding provides some evidence that female immigrants to the United Sates are more favorably selected in terms of "unobservable" characteristics that may escape the filter of a point system. Such a pattern is 
consistent with the prediction of selective migration models (Borjas 1991) that the less compressed income distribution in the United States (compared to Australia and Canada) should attract the most productive immigrant workers, particularly with respect to those attributes (such as ability and ambition) that immigration officials would have difficulty discerning prior to admission.

\section{Conclusion}

On average, women who immigrate to Australia and Canada have larger endowments of productivity-related skills than do women who immigrate to the United States. In particular, they are more likely to be fluent in the destination country language, possess more education (relative to native-born women), and have higher income (relative to native-born women) than their U.S. counterparts.

To a great extent, however, this skill disadvantage of U.S. foreign-born women arises because the United States receives a much larger share of unskilled immigrants from Latin America than do the other two countries. When we exclude women born in Central and South America, the fluency gap for U.S. immigrants is substantially reduced, and educational attainment (in absolute terms) for female immigrants is now higher in the United States than in Australia or Canada. Even when adopting a relative measure of education that compares immigrants with natives in the same destination country, the relative schooling gap of U.S. immigrants shrinks dramatically (but does not disappear entirely) once Latin American immigrants are excluded. Given these findings, and the importance of language ability and education in the earnings determination process, it is not surprising that national origin differences can account for all of the income disadvantage (relative to natives) of U.S. female immigrants compared to their Canadian counterparts, and most of the disadvantage compared to Australian immigrants. Even after excluding women originating in 
Central and South America, however, the incomes of U.S. immigrants improve relative to Australian and Canadian immigrants once controls are added for fluency and schooling. This result suggests that female immigrants to the United Sates may be more favorably selected in terms of difficult-toobserve characteristics that escape the filter of an immigration point system.

These patterns in the labor market skills of foreign-born women in Australia, Canada, and the United States are very similar to what we found previously for men (Antecol, Cobb-Clark, and Trejo, 2002), and we think our earlier interpretation of the male results applies here as well. In particular, we do not believe that our cross-country comparisons provide much support for the proposition that the skills of U.S. immigrants would improve if the United States were to adopt an immigration point system similar to those in Australia and Canada. For one thing, the skill disadvantage of U.S. immigrants is largely driven by the substantial inflows from Central and South America, and we strongly suspect that the Australian and Canadian point systems are not the primary reason that these countries receive few Latin American immigrants relative to the United States. The fact that the United States shares a wide border and a long history with Mexico undoubtedly contributes to the large presence of Latin American immigrants in the United States. Moreover, Australia and Canada never received many immigrants from Latin America, even before immigration point systems were introduced in Australia in the 1970s and Canada in the late 1960s (see Reitz, 1998, Table 1.1, pp. 1012). Another reason to doubt the efficacy of a point system in the United States is that much of U.S. immigration from Latin America is undocumented (Warren and Passel, 1987; Woodrow and Passel, 1990) and subject to limited official control (Bean, Espenshade, White, and Dymowski, 1990; Donato, Durand, and Massey, 1992; Kossoudji, 1992). Therefore, a point system that screens legal immigrants for skills may do little to raise the skills or restrict the entry of Latin American immigrants to the United States, because these immigrants seem to find it relatively easy to enter 
outside of the official admissions system.

Finally, in all three countries, men are much more likely than women to gain admission on the basis of immigration criteria related to labor market considerations rather than family relationships. For this reason, we might expect that the stronger emphasis on skill-based admissions in Australia and Canada compared to the United States would have a larger impact on cross-country differences in the skill content of male rather than female immigration flows. Therefore, our findings of similar patterns for men and women and of the key role played by national origin both suggest that factors other than immigration policy per se are important contributors to the observed skill differences between immigrants to these three destination countries. 


\section{References}

Antecol, Heather, Deborah A. Cobb-Clark, and Stephen J. Trejo. 2002. "Immigration Policy and the Skills of Immigrants to Australia, Canada, and the United States." Journal of Human Resources, forthcoming.

Bean, Frank D., Thomas J. Espenshade, Michael J. White, and Robert F. Dymowski. 1990. "PostIRCA Changes in the Volume and Composition of Undocumented Migration to the United States: An Assessment Based on Apprehensions Data." In Undocumented Migration to the United States: IRCA and the Experience of the 1980s, ed. Frank D. Bean, Barry Edmonston, and Jeffrey S. Passel, 111-58. Washington, D.C.: Urban Institute Press.

Borjas, George. J. 1988. International Differences in the Labor Market Performance of Immigrants. Kalamazoo, Mich.: W.E. Upjohn Institute for Employment Research.

. 1991. "Immigration and Self-Selection." In Immigration, Trade, and the Labor Market. John M. Abowd and Richard B. Freeman, editors. Chicago: University of Chicago Press: 29-76.

. 1993. "Immigration Policy, National Origin, and Immigrant Skills: A Comparison of Canada and the United States." In Small Differences That Matter: Labor Markets and Income Maintenance in Canada and the United States. David Card and Richard B. Freeman, editors. Chicago: University of Chicago Press: 21-43.

. 1995. "Assimilation and Changes in Cohort Quality Revisited: What Happened to Immigrant Earnings in the 1980s?" Journal of Labor Economics, April 1995, 13(2), pp. 20145.

Boyd, Monica. 1976. "Immigration Policies and Trends: A Comparison of Canada and the United States.” Demography, 18(1): 83-104.

Briggs, Vernon. M., Jr. 1984. Immigration Policy and the American Labor Force. Baltimore: The Johns Hopkins University Press.

Card, David, and Richard B. Freeman, eds. 1993. Small Differences That Matter: Labor Markets and Income Maintenance in Canada and the United States. Chicago: University of Chicago Press.

Carliner, Geoffrey. 1995. "The Language Ability of U.S. Immigrants: Assimilation and Cohort Effects.” Working Paper 5222. Cambridge, MA: NBER.

. 1996. "The Wages and Language Skills of U.S. Immigrants." Working Paper 5763. Cambridge, MA: NBER. 
Chiswick, Barry R. 1987. "Immigration Policy, Source Countries, and Immigrant Skills: Australia, Canada, and the United States." In The Economics of Immigration. Proceedings of Conference held at the Australian National University. Canberra: Australian Government Printing Service.

Cobb-Clark, Deborah A. 1990. Immigrant Selectivity: The Roles of Household Structure and U.S. Immigration Policy. PhD dissertation, Economics Department, University of Michigan. Ann Arbor: University of Michigan.

Donato, Katharine M., Jorge Durand, and Douglas S. Massey. 1992. "Stemming the Tide? Assessing the Deterrent Effects of the Immigration Reform and Control Act." Demography 29(2): 139-157.

Duleep, Harriet Orcutt and Mark C. Regets. 1992. "Some Evidence on the Effects of Admissions Criteria on Immigrant Assimilation." In Immigration, Language and Ethnic Issues: Canada and the United States. Barry R. Chiswick, editor. Washington: American Enterprise Institute: 410-439.

Evans, M.D.R., Jonathan Kelley, and Richard A. Wanner. 1998. "The Consequences of Divorce for Children's Education: Australia, Canada, and the U.S.A., 1940-1990." Unpublished Manuscript. Canberra, Australia: Australian National University.

Funkhouser, Edward. 1996. "How Much of Immigrant Wage Assimilation is Related to English Language Acquisition?” Unpublished Manuscript. Santa Barbara, CA: University of California.

Funkhouser, Edward and Stephen J. Trejo. 1998. "Labor Market Outcomes and Female Immigrants in the United States." In The Immigration Debate: Studies on Economic, Demographic, and Fiscal Effects of Immigration. James P. Smith and Barry Edmonston, editors. Washington: National Academy Press: 239-288.

Green, Alan. G. 1995. "A Comparison of Canadian and US Immigration Policy in the Twentieth Century." In Diminishing Returns: The Economics of Canada's Recent Immigration Policy. D.J. DeVortez, editor. Toronto and Vancouver: C.D. Howe Institute and The Laurier Institution.

Green, Alan G. and David A. Green. 1995. "Canadian Immigration Policy: The Effectiveness of the Point System and Other Instruments." Canadian Journal of Economics, 28(4b): 1006 - 1041.

Gregory, Robert G., and Anne E. Daly. 1994. "Welfare and Economic Progress of Indigenous Men of Australia and the U.S., 1980-1990.” Canberra: Australian National University. Mimeo. 
Heckman, James J. 1980. "Sample Selection Bias as a Specification Error." In Female Labor Supply: Theory and Estimation. J.P. Smith, editor. Princeton, NJ: Princeton University Press: 206-48.

Houstoun, Marion F., Roger G. Kramer, and Joan Mackin Barrett, 1984. "Female Predominance in Immigration in the United States Since 1930: A First Look." International Migration Review, 38 (4): 908-63.

Kossoudji, Sherrie A. 1992. "Playing Cat and Mouse at the U.S.-Mexican Border." Demography 29(2): 159-80.

Lack, John and Jacqueline Templeton. 1995. Bold Experiment: A Documentary History of Australian Immigration Since 1945. Melbourne: Oxford University Press.

Madden, Ros and Susan Young, 1993. Women and Men Immigrating to Australia: Their Characteristics and Immigration Decisions. Bureau of Immigration Research. Canberra: Australian Government Printing Service.

Price, Charles. 1979. "Australia." In The Politics of Migration Policies. Daniel Kubat, editor. New York: Center for Migration Studies: 3-18.

Reimers, David M., and Harold Troper. 1992. "Canadian and American Immigration Policy since 1945." In Immigration, Language and Ethnic Issues: Canada and the United States. Barry R. Chiswick, editor. Washington: American Enterprise Institute: 15-54.

Reitz, Jeffrey G. 1998. Warmth of the Welcome: The Social Causes of Economic Success for Immigrants in Different Nations and Cities. Boulder, Colo.: Westview Press.

Reitz, Jeffrey G., Joachim R. Frick, Tony Calabrese, and Gert C. Wagner. 1999. "The Institutional Framework of Ethnic Employment Disadvantage: A Comparison of Germany and Canada." Journal of Ethnic and Migration Studies, 25(3): 397-443.

Schoeni, Robert F. 1998. "Labor Market Assimilation of Immigrant Women.” Industrial and Labor Relations Review, 51(3): 483-504.

United Nations (UN), Department for Economic and Social Information and Policy Analysis, Population Division, 1995. International Migration Policies and the Status of Female Migrants. New York: United Nations.

Vialet, Joyce C. 1989. Immigration: Numerical Limits and the Preference System. Washington: Congressional Research Service, Library of Congress. 
Vialet, Joyce C. and Larry M. Eig. 1990. Immigration Act of 1990 (P.L. 101-649). Washington: Congressional Research Service, Library of Congress.

Warren, Robert, and Jeffrey S. Passel. 1987. "A Count of the Uncountable: Estimates of Undocumented Aliens Counted in the 1980 United States Census." Demography 24(3): 37593.

Woodrow, Karen A., and Jeffrey S. Passel. 1990. "Post-IRCA Undocumented Immigration to the United States: An Assessment Based on the June 1988 CPS." In Undocumented Migration to the United States: IRCA and the Experience of the 1980s, ed. Frank D. Bean, Barry Edmonston, and Jeffrey S. Passel, 33-72. Washington, D.C.: Urban Institute Press.

Wright, Robert E., and Paul S. Maxim. 1993. "Immigration Policy and Immigrant Quality: Empirical Evidence from Canada." Journal of Population Economics, 6(4): 337-52. 
Table 1

Region of Birth Distributions of Post-1980/81 Female Immigrant Arrivals, By Destination Country

\begin{tabular}{|c|c|c|c|}
\hline \multirow[b]{2}{*}{ Region of Birth } & \multicolumn{3}{|c|}{ Destination Country } \\
\hline & Australia & Canada & United States \\
\hline United Kingdom & 18.3 & 5.3 & 2.0 \\
\hline Europe & 12.5 & 19.3 & 8.9 \\
\hline Middle East & 4.7 & 6.5 & 3.2 \\
\hline Africa & 3.6 & 5.4 & 2.3 \\
\hline China & 4.2 & 5.9 & 3.7 \\
\hline Hong Kong & 3.2 & 8.3 & 0.7 \\
\hline Philippines & 7.6 & 7.1 & 6.9 \\
\hline Southern Asia & 4.8 & 8.7 & 3.9 \\
\hline Other Asia & 19.9 & 11.8 & 16.4 \\
\hline Central/South America & 2.5 & 16.1 & 45.6 \\
\hline United States & 2.0 & 4.5 & n.a. \\
\hline Other North America & 1.0 & n.a. & 1.7 \\
\hline Oceania/Antarctica & 15.7 & n.a. & 0.6 \\
\hline Other & n.a. & 1.1 & 4.0 \\
\hline All Regions & $100.0 \%$ & $100.0 \%$ & $100.0 \%$ \\
\hline Sample Size & 3,329 & 10,677 & 109,994 \\
\hline
\end{tabular}

Note: Data are from the 1991 Australian and Canadian censuses and the 1990 U.S. census. The samples include foreign-born women ages 25-59 who immigrated during 1981-91 in the Australian and Canadian data or during 1980-90 in the U.S. data. Entries of "n.a." indicate regions of birth that cannot be defined for a particular destination country. Columns may not sum to 100 percent because of rounding error. Sampling weights were used in the U.S. calculations. 
Table 2

Percent of Female Immigrants Fluent in Destination Country Language, By Arrival Cohort and Destination Country

\begin{tabular}{|c|c|c|c|}
\hline \multirow[b]{2}{*}{ Immigrant Cohort } & \multicolumn{3}{|c|}{ Destination Country } \\
\hline & Australia & Canada & United States \\
\hline \multirow[t]{2}{*}{ Pre-1971 Arrivals } & $\begin{array}{c}92.5 \\
(0.4)\end{array}$ & $\begin{array}{c}97.5 \\
(0.1)\end{array}$ & $\begin{array}{c}89.3 \\
(0.1)\end{array}$ \\
\hline & {$[5,291]$} & {$[17,177]$} & {$[111,652]$} \\
\hline \multirow[t]{3}{*}{ 1971-75 Arrivals } & 90.7 & 95.9 & 77.3 \\
\hline & $(0.8)$ & $(0.2)$ & $(0.2)$ \\
\hline & {$[1,320]$} & {$[6,427]$} & {$[41,656]$} \\
\hline \multirow[t]{3}{*}{ 1976-80 Arrivals } & 87.8 & 94.9 & 72.1 \\
\hline & $(1.0)$ & $(0.3)$ & $(0.2)$ \\
\hline & [1021] & {$[4,722]$} & {$[46,600]$} \\
\hline \multirow[t]{3}{*}{ 1981-85 Arrivals } & 83.5 & 92.6 & 64.0 \\
\hline & $(1.1)$ & $(0.4)$ & $(0.2)$ \\
\hline & {$[1,212]$} & {$[3,903]$} & {$[54,748]$} \\
\hline \multirow[t]{3}{*}{ 1986-91 Arrivals } & 79.1 & 86.2 & 56.2 \\
\hline & $(0.9)$ & $(0.4)$ & $(0.2)$ \\
\hline & {$[2,104]$} & {$[6,787]$} & {$[55,247]$} \\
\hline
\end{tabular}

Note: Standard errors are in parentheses, and sample sizes are in brackets. Data are from the 1991 Australian and Canadian censuses and the 1990 U.S. census. The samples include foreign-born women ages 25-59. In the Australian and U.S. data, immigrants are designated as "fluent in the destination country language" if they speak only English or else report speaking English "very well" or "well." In the Canadian data, the corresponding measure of fluency identifies immigrants who can conduct a conversation in either English or French. The intervals listed above for the immigrant arrival cohorts are those defined in the Australian and Canadian data; the slightly different immigrant cohorts defined in the U.S. data are as follows: pre-1970, 1970-74, 1975-79, 1980-84, and 1985-90. Sampling weights were used in the U.S. calculations. 
Table 3

Percent of Post-1980/81 Female Immigrant Arrivals Fluent in Destination Country Language, By Birthplace and Destination Country

\begin{tabular}{|c|c|c|c|}
\hline \multirow[b]{2}{*}{ Region of Birth } & \multicolumn{3}{|c|}{ Destination Country } \\
\hline & Australia & Canada & United States \\
\hline \multirow[t]{2}{*}{ United Kingdom } & 99.5 & 100.0 & 99.6 \\
\hline & $(0.3)$ & $()$. & $(0.1)$ \\
\hline \multirow{2}{*}{ Europe } & 72.7 & 88.7 & 76.2 \\
\hline & $(2.2)$ & $(0.7)$ & $(0.5)$ \\
\hline \multirow[t]{2}{*}{ Middle East } & 59.2 & 89.3 & 75.3 \\
\hline & (3.9) & $(1.2)$ & $(0.8)$ \\
\hline \multirow{2}{*}{ Africa } & 97.5 & 95.6 & 89.7 \\
\hline & (1.4) & $(0.9)$ & $(0.7)$ \\
\hline \multirow[t]{2}{*}{ China } & 41.4 & 55.6 & 43.4 \\
\hline & $(4.2)$ & $(2.0)$ & $(0.8)$ \\
\hline \multirow{2}{*}{ Hong Kong } & 81.0 & 92.5 & 74.2 \\
\hline & (3.8) & $(0.9)$ & (1.6) \\
\hline \multirow[t]{2}{*}{ Philippines } & 98.0 & 99.5 & 94.1 \\
\hline & $(0.8)$ & $(0.3)$ & $(0.3)$ \\
\hline \multirow[t]{2}{*}{ Southern Asia } & 95.0 & 85.6 & 83.0 \\
\hline & $(1.7)$ & $(1.2)$ & $(0.6)$ \\
\hline \multirow[t]{2}{*}{ Other Asia } & 56.9 & 78.7 & 54.0 \\
\hline & (1.9) & $(1.2)$ & $(0.4)$ \\
\hline \multirow[t]{2}{*}{ Central/South America } & 46.3 & 92.1 & 46.6 \\
\hline & $(5.5)$ & $(0.7)$ & $(0.2)$ \\
\hline \multirow[t]{2}{*}{ All Regions Listed Above } & 76.8 & 87.9 & 59.0 \\
\hline & $(0.7)$ & $(0.3)$ & $(0.2)$ \\
\hline All Regions, Excluding & 77.8 & 87.0 & 70.8 \\
\hline Central/South America & $(0.7)$ & $(0.3)$ & $(0.2)$ \\
\hline
\end{tabular}

Note: Standard errors are in parentheses. Data are from the 1991 Australian and Canadian censuses and the 1990 U.S. census. The samples include foreign-born women ages 25-59 who immigrated during 1981-91 in the Australian and Canadian data or during 1980-90 in the U.S. data. In the Australian and U.S. data, immigrants are designated as "fluent in the destination country language" if they speak only English or else report speaking English "very well" or "well." In the Canadian data, the corresponding measure of fluency identifies immigrants who can conduct a conversation in either English or French. Sampling weights were used in the U.S. calculations. 
Table 4

The Determinants of Years of Education for Female Immigrants,

By Destination Country

\begin{tabular}{|c|c|c|c|c|c|c|}
\hline \multirow[b]{3}{*}{ Regressor } & \multicolumn{6}{|c|}{ Destination Country } \\
\hline & \multicolumn{2}{|c|}{ Australia } & \multicolumn{2}{|c|}{ Canada } & \multicolumn{2}{|c|}{ United States } \\
\hline & (1) & (2) & (1) & (2) & $(1)$ & $(2)$ \\
\hline Intercept (Natives) & $\begin{array}{l}11.32 \\
(0.02)\end{array}$ & $\begin{array}{l}11.51 \\
(0.03)\end{array}$ & $\begin{array}{c}12.57 \\
(0.01)\end{array}$ & $\begin{array}{l}13.25 \\
(0.01)\end{array}$ & $\begin{array}{l}13.15 \\
(0.01)\end{array}$ & $\begin{array}{c}13.38 \\
(0.02)\end{array}$ \\
\hline Immigrant Cohort: & & & & & & \\
\hline Pre-1971 Arrivals & $\begin{array}{l}-0.12 \\
(0.04)\end{array}$ & $\begin{array}{c}0.01 \\
(0.04)\end{array}$ & $\begin{array}{l}-0.73 \\
(0.03)\end{array}$ & $\begin{array}{l}-0.20 \\
(0.03)\end{array}$ & $\begin{array}{l}-1.15 \\
(0.02)\end{array}$ & $\begin{array}{l}-0.98 \\
(0.02)\end{array}$ \\
\hline 1971-75 Arrivals & $\begin{array}{c}0.31 \\
(0.07)\end{array}$ & $\begin{array}{c}0.35 \\
(0.07)\end{array}$ & $\begin{array}{l}-0.21 \\
(0.05)\end{array}$ & $\begin{array}{l}-0.17 \\
(0.04)\end{array}$ & $\begin{array}{l}-1.93 \\
(0.03)\end{array}$ & $\begin{array}{l}-1.98 \\
(0.03)\end{array}$ \\
\hline 1976-80 Arrivals & $\begin{array}{c}0.71 \\
(0.08)\end{array}$ & $\begin{array}{c}0.67 \\
(0.08)\end{array}$ & $\begin{array}{l}-0.10 \\
(0.05)\end{array}$ & $\begin{array}{l}-0.19 \\
(0.05)\end{array}$ & $\begin{array}{l}-2.04 \\
(0.03)\end{array}$ & $\begin{array}{l}-2.16 \\
(0.03)\end{array}$ \\
\hline 1981-85 Arrivals & $\begin{array}{c}0.86 \\
(0.07)\end{array}$ & $\begin{array}{c}0.80 \\
(0.07)\end{array}$ & $\begin{array}{l}-0.11 \\
(0.06)\end{array}$ & $\begin{array}{l}-0.27 \\
(0.05)\end{array}$ & $\begin{array}{l}-2.09 \\
(0.02)\end{array}$ & $\begin{array}{l}-2.22 \\
(0.02)\end{array}$ \\
\hline 1986-91 Arrivals & $\begin{array}{c}1.34 \\
(0.06)\end{array}$ & $\begin{array}{c}1.25 \\
(0.06)\end{array}$ & $\begin{array}{l}-0.03 \\
(0.04)\end{array}$ & $\begin{array}{l}-0.25 \\
(0.04)\end{array}$ & $\begin{array}{l}-1.58 \\
(0.02)\end{array}$ & $\begin{array}{l}-1.71 \\
(0.02)\end{array}$ \\
\hline Age Group: & & & & & & \\
\hline $30-34$ & & $\begin{array}{c}0.09 \\
(0.04)\end{array}$ & & $\begin{array}{l}-0.20 \\
(0.02)\end{array}$ & & $\begin{array}{c}0.04 \\
(0.03)\end{array}$ \\
\hline $35-39$ & & $\begin{array}{l}-0.03 \\
(0.04)\end{array}$ & & $\begin{array}{l}-0.25 \\
(0.02)\end{array}$ & & $\begin{array}{c}0.10 \\
(0.04)\end{array}$ \\
\hline $40-44$ & & $\begin{array}{l}-0.26 \\
(0.04)\end{array}$ & & $\begin{array}{l}-0.55 \\
(0.02)\end{array}$ & & $\begin{array}{c}0.04 \\
(0.04)\end{array}$ \\
\hline $45-49$ & & $\begin{array}{l}-0.47 \\
(0.05)\end{array}$ & & $\begin{array}{l}-1.12 \\
(0.02)\end{array}$ & & $\begin{array}{l}-0.39 \\
(0.04)\end{array}$ \\
\hline $50-54$ & & $\begin{array}{l}-0.71 \\
(0.05)\end{array}$ & & $\begin{array}{l}-1.85 \\
(0.03)\end{array}$ & & $\begin{array}{l}-0.88 \\
(0.04)\end{array}$ \\
\hline $55-59$ & & $\begin{array}{l}-0.86 \\
(0.06)\end{array}$ & & $\begin{array}{l}-2.53 \\
(0.03)\end{array}$ & & $\begin{array}{l}-1.22 \\
(0.04)\end{array}$ \\
\hline
\end{tabular}

Note: The dependent variable is years of schooling. The coefficients were estimated by least squares, and robust standard errors are shown in parentheses. Data are from the 1991 Australian and Canadian censuses and the 1990 U.S. census. The samples include women ages 25-59, with non-whites excluded from the native but not the foreign-born samples. The sample sizes for these regressions are 31,291 for Australia, 181,277 for Canada, and 354,426 for the United States. The intervals listed above for the immigrant arrival cohorts are those defined in the Australian and Canadian data; the slightly different immigrant cohorts defined in the U.S. data are as follows: pre-1970, 1970-74, 1975-79, 1980-84, and 1985-90. The reference group for the age dummies is 25-29 year-olds. Sampling weights were used in the U.S. calculations. 
Table 5

Average and Relative Education of Post-1980/81 Female Immigrant Arrivals, By Birthplace and Destination Country

\begin{tabular}{|c|c|c|c|c|c|c|}
\hline \multirow[b]{2}{*}{ Region of Birth } & \multicolumn{3}{|c|}{ Average Years of Schooling } & \multicolumn{3}{|c|}{ Schooling Relative to Natives } \\
\hline & Australia & Canada & U.S. & Australia & Canada & U.S. \\
\hline \multirow[t]{2}{*}{ United Kingdom } & 11.95 & 13.59 & 13.69 & 0.63 & 1.03 & 0.54 \\
\hline & $(0.10)$ & $(0.08)$ & $(0.05)$ & $(0.10)$ & $(0.08)$ & $(0.05)$ \\
\hline \multirow[t]{2}{*}{ Europe } & 12.65 & 12.89 & 13.22 & 1.34 & 0.33 & 0.07 \\
\hline & $(0.13)$ & $(0.08)$ & $(0.04)$ & $(0.13)$ & $(0.08)$ & $(0.04)$ \\
\hline \multirow[t]{2}{*}{ Middle East } & 12.72 & 12.61 & 12.67 & 1.41 & 0.05 & -0.48 \\
\hline & $(0.22)$ & $(0.14)$ & $(0.07)$ & $(0.22)$ & $(0.14)$ & $(0.07)$ \\
\hline \multirow[t]{2}{*}{ Africa } & 12.63 & 12.89 & 13.50 & 1.31 & 0.33 & 0.35 \\
\hline & $(0.21)$ & $(0.13)$ & $(0.07)$ & $(0.21)$ & $(0.13)$ & $(0.07)$ \\
\hline \multirow[t]{2}{*}{ China } & 12.81 & 11.04 & 11.70 & 1.50 & -1.52 & -1.45 \\
\hline & $(0.20)$ & $(0.17)$ & $(0.08)$ & $(0.20)$ & $(0.17)$ & $(0.08)$ \\
\hline \multirow[t]{2}{*}{ Hong Kong } & 13.24 & 13.28 & 12.86 & 1.93 & 0.72 & -0.29 \\
\hline & $(0.18)$ & $(0.08)$ & $(0.13)$ & $(0.18)$ & $(0.08)$ & $(0.13)$ \\
\hline \multirow[t]{2}{*}{ Philippines } & 13.35 & 13.80 & 14.04 & 2.03 & 1.24 & 0.90 \\
\hline & $(0.15)$ & $(0.10)$ & $(0.04)$ & $(0.15)$ & $(0.10)$ & $(0.04)$ \\
\hline \multirow{2}{*}{ Southern Asia } & 13.44 & 11.97 & 14.17 & 2.12 & -0.59 & 1.03 \\
\hline & $(0.21)$ & $(0.13)$ & $(0.07)$ & $(0.21)$ & $(0.13)$ & $(0.07)$ \\
\hline \multirow[t]{2}{*}{ Other Asia } & 12.71 & 10.94 & 11.75 & 1.39 & -1.62 & -1.40 \\
\hline & $(0.08)$ & $(0.12)$ & $(0.04)$ & $(0.08)$ & $(0.12)$ & $(0.04)$ \\
\hline \multirow[t]{2}{*}{ Central/South America } & 13.10 & 12.01 & 9.67 & 1.78 & -0.55 & -3.48 \\
\hline & $(0.23)$ & $(0.08)$ & $(0.02)$ & $(0.23)$ & $(0.08)$ & $(0.02)$ \\
\hline \multirow[t]{2}{*}{ All Regions Listed Above } & 12.63 & 12.42 & 11.27 & 1.32 & -0.14 & -1.88 \\
\hline & $(0.05)$ & $(0.03)$ & $(0.01)$ & $(0.05)$ & $(0.03)$ & $(0.01)$ \\
\hline All Regions, Excluding & 12.62 & 12.50 & 12.79 & 1.31 & -0.06 & -0.36 \\
\hline Central/South America & $(0.05)$ & $(0.04)$ & $(0.02)$ & $(0.05)$ & $(0.04)$ & $(0.02)$ \\
\hline
\end{tabular}

Note: Robust standard errors are in parentheses. Data are from the 1991 Australian and Canadian censuses and the 1990 U.S. census. The samples include women ages 25-59, with non-whites excluded from the native but not the foreign-born samples. The foreign-born samples are limited to women who immigrated during 1981-91 in the Australian and Canadian data or during 198090 in the U.S. data. Sampling weights were used in the U.S. calculations. 
Table 6

The Effect of Immigrant Cohort on Female Immigrant Income, By Destination Country

\begin{tabular}{|c|c|c|c|c|c|c|}
\hline \multirow[b]{3}{*}{ Regressor } & \multicolumn{6}{|c|}{ "Destination Country } \\
\hline & \multicolumn{2}{|c|}{ Australia } & \multicolumn{2}{|c|}{ Canada } & \multicolumn{2}{|c|}{ United States } \\
\hline & $(1)$ & $(2)$ & $(1)$ & $(2)$ & $(1)$ & $(2)$ \\
\hline \multicolumn{7}{|l|}{ Immigrant Cohort: } \\
\hline \multirow[t]{2}{*}{ Pre-1971 Arrivals } & -.027 & .004 & .122 & .068 & .064 & .169 \\
\hline & $(.024)$ & $(.025)$ & $(.016)$ & $(.016)$ & $(.014)$ & $(.017)$ \\
\hline \multirow[t]{2}{*}{ 1971-75 Arrivals } & .021 & .031 & .047 & .008 & -.036 & .153 \\
\hline & $(.029)$ & $(.029)$ & $(.018)$ & $(.018)$ & $(.015)$ & $(.020)$ \\
\hline \multirow[t]{2}{*}{ 1976-80 Arrivals } & .002 & .016 & -.004 & -.036 & -.109 & .105 \\
\hline & $(.033)$ & $(.034)$ & $(.020)$ & $(.019)$ & $(.015)$ & $(.020)$ \\
\hline \multirow[t]{2}{*}{ 1981-85 Arrivals } & -.055 & -.035 & -.113 & -.127 & -.236 & -.001 \\
\hline & $(.027)$ & $(.028)$ & $(.020)$ & $(.020)$ & $(.015)$ & $(.020)$ \\
\hline \multirow[t]{2}{*}{ 1986-91 Arrivals } & -.074 & -.057 & -.342 & -.352 & -.413 & -.197 \\
\hline & $(.026)$ & $(.026)$ & $(.019)$ & $(.019)$ & $(.016)$ & $(.021)$ \\
\hline $\mathrm{R}^{2}$ & .321 & .373 & .137 & .186 & .278 & .328 \\
\hline Sample Size & 20,612 & 18,396 & 139,342 & 139,333 & 240,423 & 240,423 \\
\hline \multicolumn{7}{|l|}{ Control Variables: } \\
\hline Age Dummies & Yes & Yes & Yes & Yes & Yes & Yes \\
\hline Education & No & Yes & No & Yes & No & Yes \\
\hline Fluency Dummies & No & Yes & No & Yes & No & Yes \\
\hline
\end{tabular}

Note: The dependent variable is the natural logarithm of weekly personal income. The coefficients were estimated by least squares, and robust standard errors are shown in parentheses. Data are from the 1991 Australian and Canadian censuses and the 1990 U.S. census. The samples include women ages 25-59, with non-whites excluded from the native but not the foreign-born samples. Only employed women are included in the samples. The income and employment measures in the Australian data refer to the usual week and the census survey week, respectively, whereas in the Canadian and U.S. data these measures refer to the calendar year preceding the census. In addition to the control variables listed above, all regressions include indicators for geographic location and hours worked during the census survey week. The coefficients of the controls for geographic location, weekly hours of work, and fluency are restricted to be the same for immigrants and natives, whereas the coefficients of the age and education variables are allowed to vary by nativity. The intervals listed above for the immigrant arrival cohorts are those defined in the Australian and Canadian data; the slightly different immigrant cohorts defined in the U.S. data are as follows: pre-1970, 1970-74, 1975-79, 1980-84, and 1985-90. The immigrant cohort coefficients reported in this table have been normalized to represent immigrant-native income differentials for women who are aged 25-29 (in both specifications) and who have 12 years of education (in specification (2)). Sampling weights were used in the U.S. calculations. 
Table 7

The Effect of Age, Education, and Language Fluency on Female Immigrant Income, By Destination Country

\begin{tabular}{|c|c|c|c|c|c|c|}
\hline \multirow[b]{3}{*}{ Regressor } & \multicolumn{6}{|c|}{ Destination Country } \\
\hline & \multicolumn{2}{|c|}{ Australia } & \multicolumn{2}{|c|}{ Canada } & \multicolumn{2}{|c|}{ United States } \\
\hline & $(1)$ & $(2)$ & $(1)$ & $(2)$ & $(1)$ & $(2)$ \\
\hline \multicolumn{7}{|l|}{ Age Group: } \\
\hline $30-34$ & $\begin{array}{c}.056 \\
(016)\end{array}$ & $\begin{array}{c}.051 \\
(016)\end{array}$ & $\begin{array}{c}.103 \\
(008)\end{array}$ & $\begin{array}{c}.092 \\
(008)\end{array}$ & $\begin{array}{c}.091 \\
(018)\end{array}$ & $\begin{array}{c}.091 \\
(017)\end{array}$ \\
\hline $35-39$ & $\begin{array}{l}.044 \\
(.016)\end{array}$ & $\begin{array}{c}.051 \\
(.016)\end{array}$ & $\begin{array}{l}.149 \\
(.009)\end{array}$ & $\begin{array}{l}.143 \\
(.009)\end{array}$ & $\begin{array}{l}.138 \\
(.018)\end{array}$ & $\begin{array}{l}.131 \\
(.017)\end{array}$ \\
\hline $40-44$ & $\begin{array}{c}.009 \\
(.016)\end{array}$ & $\begin{array}{c}.049 \\
(.016)\end{array}$ & $\begin{array}{c}.208 \\
(.009)\end{array}$ & $\begin{array}{c}.228 \\
(.009)\end{array}$ & $\begin{array}{l}.163 \\
(.018)\end{array}$ & $\begin{array}{l}.160 \\
(.017)\end{array}$ \\
\hline $45-49$ & $\begin{array}{l}-.010 \\
(.018)\end{array}$ & $\begin{array}{c}.044 \\
(.018)\end{array}$ & $\begin{array}{c}.188 \\
(.010)\end{array}$ & $\begin{array}{c}.247 \\
(.010)\end{array}$ & $\begin{array}{l}.167 \\
(.019)\end{array}$ & $\begin{array}{c}.196 \\
(.018)\end{array}$ \\
\hline $50-54$ & $\begin{array}{l}-.008 \\
(.020)\end{array}$ & $\begin{array}{c}.067 \\
(.021)\end{array}$ & $\begin{array}{l}.141 \\
(.011)\end{array}$ & $\begin{array}{c}.244 \\
(.011)\end{array}$ & $\begin{array}{l}.137 \\
(.021)\end{array}$ & $\begin{array}{c}.207 \\
(.021)\end{array}$ \\
\hline $55-59$ & $\begin{array}{l}-.056 \\
(.028)\end{array}$ & $\begin{array}{c}.052 \\
(.030)\end{array}$ & $\begin{array}{l}.145 \\
(.013)\end{array}$ & $\begin{array}{c}.288 \\
(.013)\end{array}$ & $\begin{array}{l}.175 \\
(.023)\end{array}$ & $\begin{array}{c}.263 \\
(.023)\end{array}$ \\
\hline \multicolumn{7}{|l|}{ Immigrant×Age Group: } \\
\hline $30-34$ & $\begin{array}{l}-.035 \\
(.031)\end{array}$ & $\begin{array}{l}-.006 \\
(.032)\end{array}$ & $\begin{array}{l}-.123 \\
(.020)\end{array}$ & $\begin{array}{c}.042 \\
(.020)\end{array}$ & $\begin{array}{l}-.025 \\
(.019)\end{array}$ & $\begin{array}{l}-.011 \\
(.019)\end{array}$ \\
\hline $35-39$ & $\begin{array}{l}-.014 \\
(.031)\end{array}$ & $\begin{array}{c}.001 \\
(.031)\end{array}$ & $\begin{array}{l}-.131 \\
(.020)\end{array}$ & $\begin{array}{c}.024 \\
(.020)\end{array}$ & $\begin{array}{l}-.044 \\
(.019)\end{array}$ & $\begin{array}{l}-.006 \\
(.019)\end{array}$ \\
\hline $40-44$ & $\begin{array}{l}-.033 \\
(.031)\end{array}$ & $\begin{array}{l}-.024 \\
(.031)\end{array}$ & $\begin{array}{l}-.167 \\
(.020)\end{array}$ & $\begin{array}{l}-.031 \\
(.020)\end{array}$ & $\begin{array}{l}-.074 \\
(.020)\end{array}$ & $\begin{array}{l}-.022 \\
(.019)\end{array}$ \\
\hline $45-49$ & $\begin{array}{l}-.025 \\
(.033)\end{array}$ & $\begin{array}{l}-.005 \\
(.035)\end{array}$ & $\begin{array}{l}-.153 \\
(.021)\end{array}$ & $\begin{array}{l}-.034 \\
(.021)\end{array}$ & $\begin{array}{l}-.092 \\
(.021)\end{array}$ & $\begin{array}{l}-.037 \\
(.020)\end{array}$ \\
\hline $50-54$ & $\begin{array}{l}-.076 \\
(.038)\end{array}$ & $\begin{array}{l}-.071 \\
(.040)\end{array}$ & $\begin{array}{l}-.140 \\
(.023)\end{array}$ & $\begin{array}{l}-.022 \\
(.023)\end{array}$ & $\begin{array}{l}-.084 \\
(.023)\end{array}$ & $\begin{array}{l}-.043 \\
(.022)\end{array}$ \\
\hline $55-59$ & $\begin{array}{c}.028 \\
(.050)\end{array}$ & $\begin{array}{l}-.011 \\
(.054)\end{array}$ & $\begin{array}{l}-.160 \\
(.025)\end{array}$ & $\begin{array}{l}-.052 \\
(.025)\end{array}$ & $\begin{array}{l}-.140 \\
(.025)\end{array}$ & $\begin{array}{l}-.084 \\
(.025)\end{array}$ \\
\hline Education & & $\begin{array}{c}.066 \\
(.002)\end{array}$ & & $\begin{array}{c}.093 \\
(.001)\end{array}$ & & $\begin{array}{c}.104 \\
(.002)\end{array}$ \\
\hline Immigrant $\times$ Education & & $\begin{array}{l}-.012 \\
(.004)\end{array}$ & & $\begin{array}{l}-.038 \\
(.001)\end{array}$ & & $\begin{array}{l}-.047 \\
(.003)\end{array}$ \\
\hline $\begin{array}{l}\text { Ability to Speak English } \\
\text { (or French in Canada): }\end{array}$ & & & & & & \\
\hline Well or Very Well & & $\begin{array}{l}-.107 \\
(.015)\end{array}$ & & $\begin{array}{l}-.073 \\
(.011)\end{array}$ & & $\begin{array}{l}-.035 \\
(.018)\end{array}$ \\
\hline Not at All or Not Well & & $\begin{array}{l}-.326 \\
(.039)\end{array}$ & & $\begin{array}{l}-.041 \\
(.030)\end{array}$ & & $\begin{array}{l}-.182 \\
(.023)\end{array}$ \\
\hline
\end{tabular}

Note: These coefficients are from the same income regressions as Table 6; see the note to that table for more information. Robust standard errors are shown in parentheses. The reference group for the age dummies is 25-29 year-olds. The reference group for the fluency dummies is women who speak only English in the Australian and U.S. data, and women who speak only English and/or French in the Canadian data. 
Table 8

The Effect of Immigrant Cohort on Female Immigrant Income, Excluding Immigrants from Central/South America, by Destination Country

\begin{tabular}{|c|c|c|c|c|c|c|}
\hline \multirow[b]{3}{*}{ Regressor } & \multicolumn{6}{|c|}{ "Destination Country } \\
\hline & \multicolumn{2}{|c|}{ Australia } & \multicolumn{2}{|c|}{ Canada } & \multicolumn{2}{|c|}{ United States } \\
\hline & $(1)$ & $(2)$ & $(1)$ & $(2)$ & $(1)$ & $(2)$ \\
\hline \multicolumn{7}{|l|}{ Immigrant Cohort: } \\
\hline \multirow[t]{2}{*}{ Pre-1971 Arrivals } & -.026 & .008 & .115 & .071 & .123 & .178 \\
\hline & $(.024)$ & $(.025)$ & $(.017)$ & $(.017)$ & $(.015)$ & $(.017)$ \\
\hline \multirow[t]{2}{*}{ 1971-75 Arrivals } & .027 & .036 & .052 & .024 & .091 & .177 \\
\hline & $(.029)$ & $(.029)$ & $(.020)$ & $(.019)$ & $(.017)$ & $(.021)$ \\
\hline \multirow[t]{2}{*}{ 1976-80 Arrivals } & .000 & .015 & .007 & -.017 & .028 & .131 \\
\hline & $(.033)$ & $(.034)$ & $(.021)$ & $(.021)$ & $(.016)$ & $(.022)$ \\
\hline \multirow[t]{2}{*}{ 1981-85 Arrivals } & -.054 & -.033 & -.101 & -.109 & -.090 & .026 \\
\hline & $(.027)$ & $(.028)$ & $(.022)$ & $(.022)$ & $(.016)$ & $(.023)$ \\
\hline \multirow[t]{2}{*}{ 1986-91 Arrivals } & -.069 & -.053 & -.338 & -.341 & -.293 & -.191 \\
\hline & $(.026)$ & $(.027)$ & $(.021)$ & $(.021)$ & $(.017)$ & $(.024)$ \\
\hline $\mathrm{R}^{2}$ & .321 & .373 & .137 & .187 & .282 & .330 \\
\hline Sample Size & 20,512 & 18,319 & 135,370 & 135,361 & 154,769 & 154,769 \\
\hline \multicolumn{7}{|l|}{ Control Variables: } \\
\hline Age Dummies & Yes & Yes & Yes & Yes & Yes & Yes \\
\hline Education & No & Yes & No & Yes & No & Yes \\
\hline Fluency Dummies & No & Yes & No & Yes & No & Yes \\
\hline
\end{tabular}

Note: The dependent variable is the natural logarithm of weekly personal income. The coefficients were estimated by least squares, and robust standard errors are shown in parentheses. Data are from the 1991 Australian and Canadian censuses and the 1990 U.S. census. The samples include women ages 25-59, with non-whites excluded from the native but not the foreign-born samples. Only employed women are included in the samples. These particular regressions exclude immigrants born in Central and South America. The income and employment measures in the Australian data refer to the usual week and the census survey week, respectively, whereas in the Canadian and U.S. data these measures refer to the calendar year preceding the census. In addition to the control variables listed above, all regressions include indicators for geographic location and hours worked during the census survey week. The coefficients of the controls for geographic location, weekly hours of work, and fluency are restricted to be the same for immigrants and natives, whereas the coefficients of the age and education variables are allowed to vary by nativity. The intervals listed above for the immigrant arrival cohorts are those defined in the Australian and Canadian data; the slightly different immigrant cohorts defined in the U.S. data are as follows: pre-1970, 1970-74, 1975-79, 1980-84, and 1985-90. The immigrant cohort coefficients reported in this table have been normalized to represent immigrant-native income differentials for women who are aged 25-29 (in both specifications) and who have 12 years of education (in specification (2)). Sampling weights were used in the U.S. calculations. 
Table 9

The Effect of Age, Education, and Language Fluency on Female Immigrant Income,

Excluding Immigrants from Central/South America, by Destination Country

\begin{tabular}{|c|c|c|c|c|c|c|}
\hline \multirow[b]{3}{*}{ Regressor } & \multicolumn{6}{|c|}{ Destination Country } \\
\hline & \multicolumn{2}{|c|}{ Australia } & \multicolumn{2}{|c|}{ Canada } & \multicolumn{2}{|c|}{ United States } \\
\hline & $(1)$ & $(2)$ & $(1)$ & $(2)$ & $(1)$ & $(2)$ \\
\hline \multicolumn{7}{|l|}{ Age Group: } \\
\hline \multirow[t]{2}{*}{$30-34$} & .057 & .051 & .099 & .093 & .091 & .091 \\
\hline & $(.016)$ & $(.016)$ & $(.008)$ & $(.008)$ & $(.018)$ & $(.017)$ \\
\hline \multirow[t]{2}{*}{$35-39$} & .044 & .051 & .144 & .143 & .137 & .131 \\
\hline & $(.016)$ & $(.016)$ & $(.009)$ & (.009) & $(.018)$ & $(.017)$ \\
\hline \multirow[t]{2}{*}{$40-44$} & .009 & .050 & .204 & .228 & .162 & .159 \\
\hline & $(.016)$ & $(.016)$ & $(.009)$ & $(.009)$ & $(.018)$ & $(.017)$ \\
\hline \multirow[t]{2}{*}{$45-49$} & -.009 & .045 & .184 & .247 & .167 & .195 \\
\hline & $(.018)$ & $(.018)$ & $(.010)$ & $(.010)$ & $(.019)$ & $(.018)$ \\
\hline \multirow[t]{2}{*}{$50-54$} & -.008 & .068 & .137 & .244 & .137 & .206 \\
\hline & $(.020)$ & $(.021)$ & $(.011)$ & $(.011)$ & $(.021)$ & $(.021)$ \\
\hline \multirow[t]{2}{*}{$55-59$} & -.056 & .053 & .141 & .290 & .175 & .263 \\
\hline & $(.028)$ & $(.030)$ & $(.013)$ & $(.013)$ & $(.023)$ & $(.023)$ \\
\hline \multicolumn{7}{|l|}{ Immigrant $\times$ Age Group: } \\
\hline \multirow[t]{2}{*}{$30-34$} & -.038 & -.012 & -.118 & .041 & -.016 & -.010 \\
\hline & $(.031)$ & $(.032)$ & $(.021)$ & $(.022)$ & $(.020)$ & $(.020)$ \\
\hline \multirow[t]{2}{*}{$35-39$} & -.016 & -.005 & -.136 & .015 & -.049 & -.019 \\
\hline & $(.031)$ & $(.031)$ & $(.021)$ & $(.021)$ & $(.020)$ & $(.020)$ \\
\hline \multirow[t]{2}{*}{$40-44$} & -.034 & -.026 & -.158 & -.028 & -.087 & -.040 \\
\hline & $(.031)$ & $(.031)$ & $(.021)$ & $(.021)$ & $(.021)$ & $(.020)$ \\
\hline \multirow[t]{2}{*}{$45-49$} & -.023 & -.007 & -.143 & -.029 & -.092 & -.048 \\
\hline & $(.033)$ & $(.035)$ & $(.022)$ & $(.022)$ & $(.022)$ & $(.021)$ \\
\hline \multirow[t]{2}{*}{$50-54$} & -.078 & -.074 & -.137 & -.020 & -.097 & -.058 \\
\hline & $(.038)$ & $(.040)$ & $(.025)$ & $(.024)$ & $(.024)$ & $(.024)$ \\
\hline \multirow[t]{2}{*}{$55-59$} & .028 & -.013 & -.160 & -.054 & -.155 & -.096 \\
\hline & $(.049)$ & $(.054)$ & $(.027)$ & $(.027)$ & $(.026)$ & $(.026)$ \\
\hline \multirow[t]{2}{*}{ Education } & & .066 & & .093 & & .103 \\
\hline & & $(.002)$ & & $(.001)$ & & $(.002)$ \\
\hline \multirow[t]{2}{*}{ Immigrant $\times$ Education } & & -.012 & & -.038 & & -.044 \\
\hline & & $(.004)$ & & $(.002)$ & & $(.003)$ \\
\hline \multicolumn{7}{|l|}{$\begin{array}{l}\text { Ability to Speak English } \\
\text { (or French in Canada): }\end{array}$} \\
\hline \multirow[t]{2}{*}{ Well or Very Well } & & -.107 & & -.078 & & -.015 \\
\hline & & $(.016)$ & & $(.012)$ & & $(.022)$ \\
\hline \multirow[t]{2}{*}{ Not at All or Not Well } & & -.327 & & -.042 & & -.118 \\
\hline & & $(.041)$ & & $(.031)$ & & $(.038)$ \\
\hline
\end{tabular}

Note: These coefficients are from the same income regressions reported in Table 8; see the note to that table for more information. Robust standard errors are shown in parentheses. The reference group for the age dummies is $25-29$ year-olds. The reference group for the fluency dummies is women who speak only English in the Australian and U.S. data, and women who speak only English and/or French in the Canadian data. 
Figure 1

Predicted Immigrant-Native Income Differentials
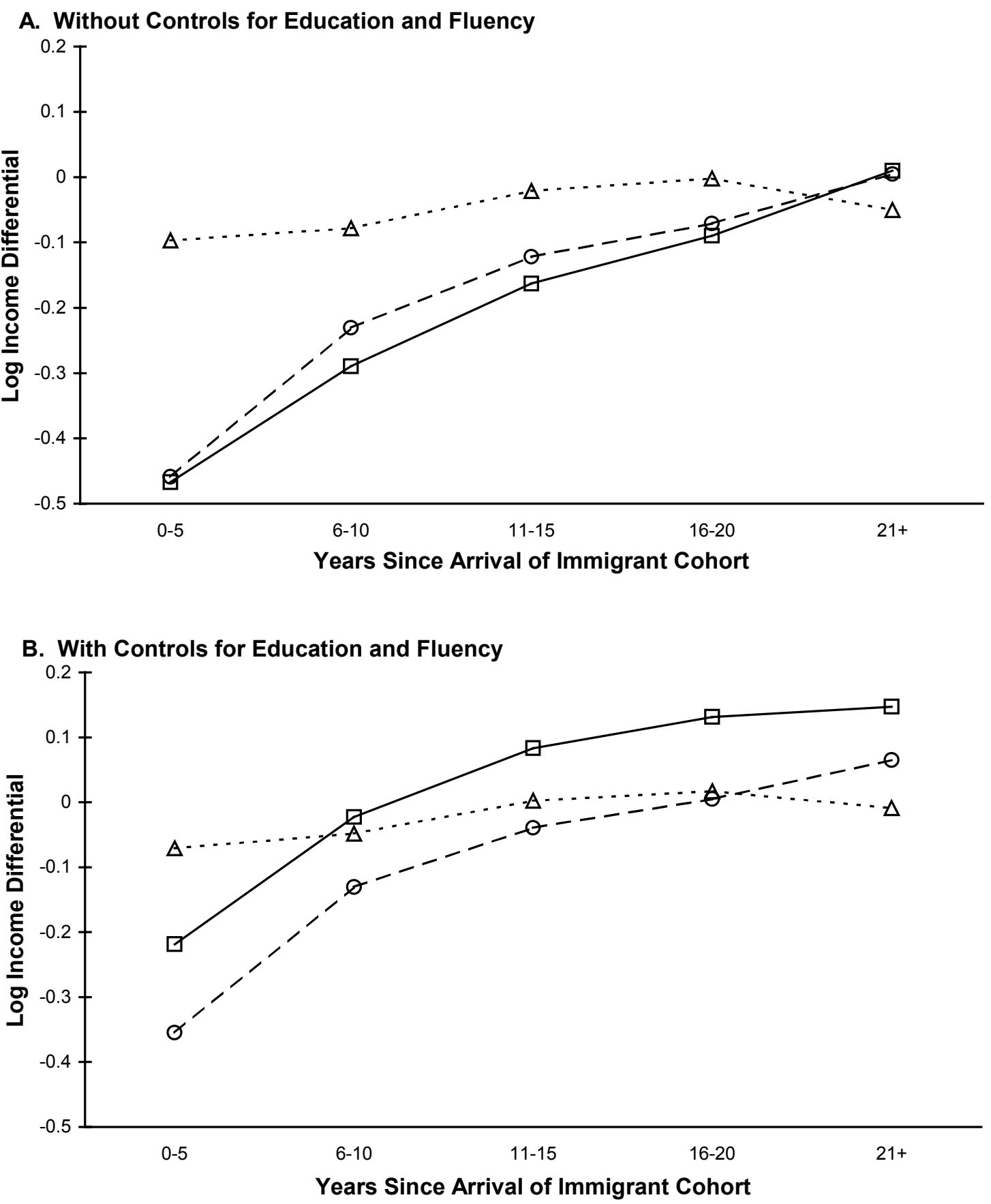

$$
\text { - - - Australia } \quad-\ominus-\text { Canada } \quad \square-\text { U.S. }
$$


Figure 2

Predicted Immigrant-Native Income Differentials

Excluding Latin American Immigrants

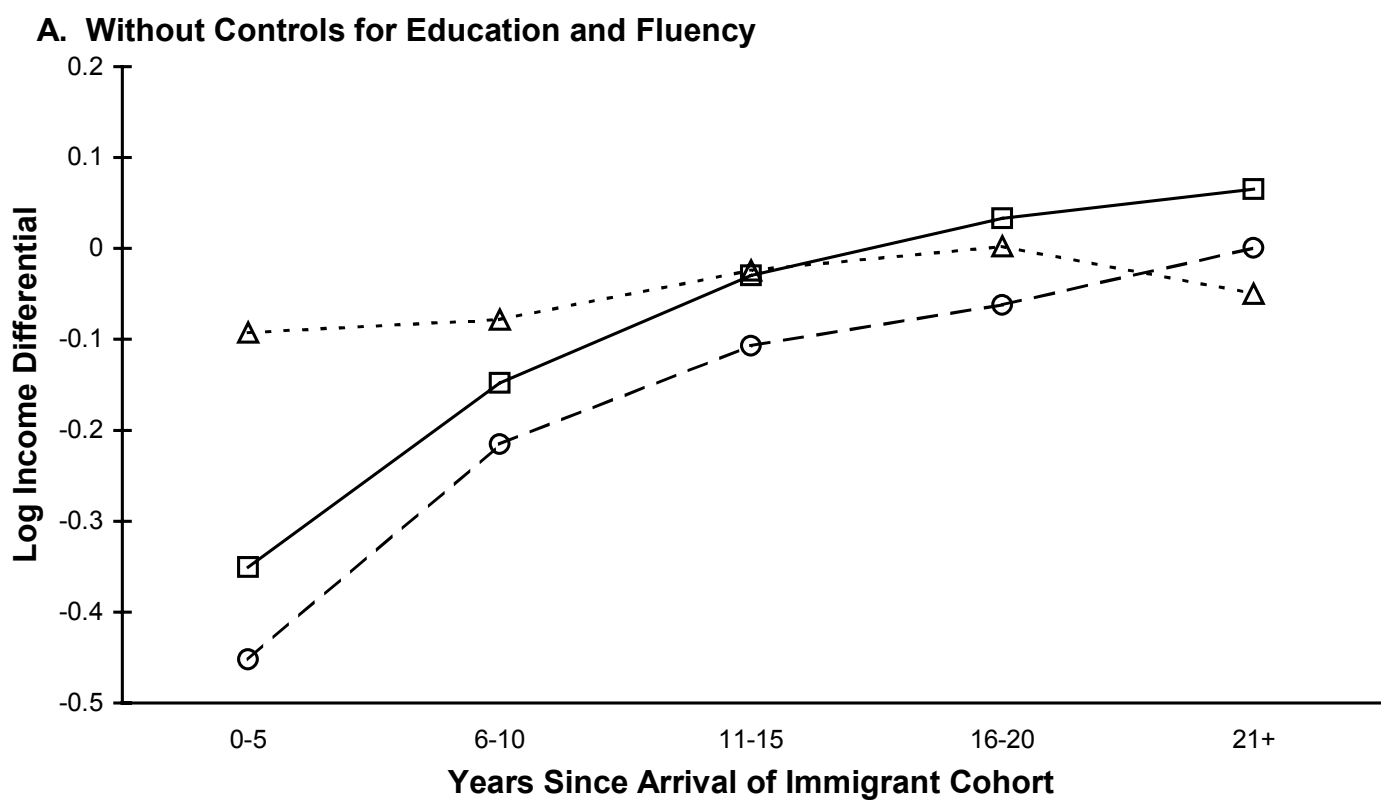

B. With Controls for Education and Fluency

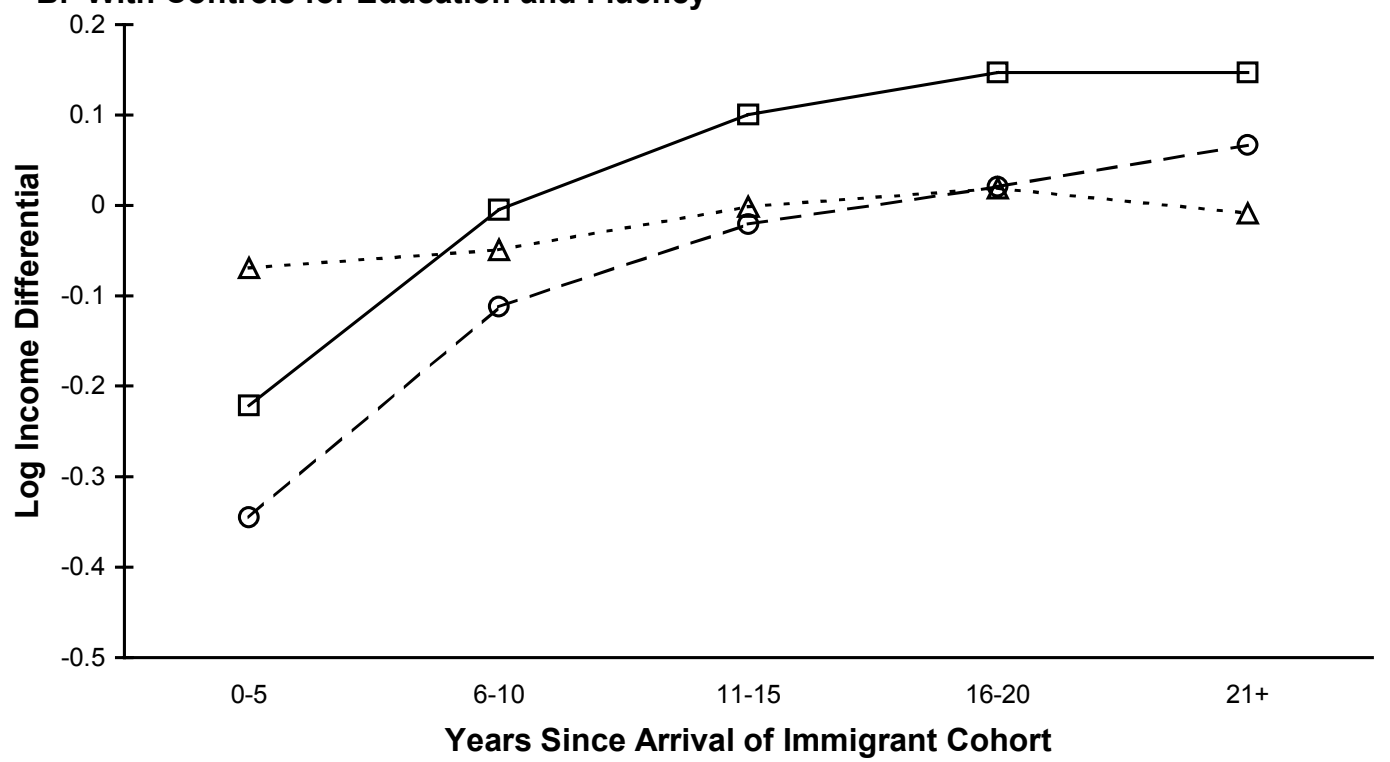

$$
\cdots \Delta-\text { Australia } \quad-\ominus-\text { Canada } \square \text { U.S. }
$$




\section{IZA Discussion Papers}

No. Author(s)

561

562

563

564

565

566

567

568

569

570

571

572

573

574

575
W. J. Carrington

P. R. Mueser

K. R. Troske

J. T. Addison

W. S. Siebert

T. Dunne

L. Foster

J. Haltiwanger

K. R. Troske

J. D. Brown

J. S. Earle

H. L. van Kranenburg

F. C. Palm

G. A. Pfann

R. Hujer

M. Caliendo

D. Radić

H. Lehmann

K. Phillips

J. Wadsworth

H. O. Duleep

D. J. Dowhan

J. Haltiwanger

M. Vodopivec

T. K. Bauer

S. Bender

O. Ashenfelter

M. Greenstone

C. Y. Co

I. N. Gang

M.-S. Yun

\section{R. T. Riphahn}

O. Serfling

R. Kuhn

S. Stillman

H. Antecol

D. A. Cobb-Clark

S. J. Trejo
Title

Area

Date

The Impact of Welfare Reform on Leaver

3

08/02

Characteristics, Employment and Recidivism

Changes in Collective Bargaining in the U.K.

3

08/02

Wage and Productivity Dispersion in U.S.

5

$08 / 02$

Manufacturing: The Role of Computer

Investment

The Reallocation of Workers and Jobs in

4

Russian Industry: New Evidence on Measures and Determinants

Survival in a Concentrating Industry: The Case

of Daily Newspapers in the Netherlands

3

09/02

Skill Biased Technological and Organizational

Change: Estimating a Mixed Simultaneous

Equation Model Using the IAB Establishment

Panel

The Incidence and Cost of Job Loss in a

Transition Economy: Displaced Workers in

Estonia, 1989-1999

Revisiting the Family Investment Model with

Longitudinal Data: The Earnings Growth of

Immigrant and U.S.-Born Women

Worker Flows, Job Flows and Firm Wage

4

09/02

Policies: An Analysis of Slovenia

Technological Change, Organizational

Change, and Job Turnover

09/02

Using Mandated Speed Limits to Measure the

Value of a Statistical Life

Self-Employment and Wage Earning:

Hungary During Transition

4

09/02

Item Non-Response on Income and Wealth

6

09/02

Questions

Understanding Interhousehold Transfers in a

4

09/02

Transition Economy: Evidence from Russia

Human Capital and Earnings of Female

Immigrants to Australia, Canada, and the

5

09/02

United States

An updated list of IZA Discussion Papers is available on the center's homepage www.iza.org. 